\title{
Field observations of mating behavior in the neck-banded snake Scaphiodontophis annulatus (Serpentes: Colubridae)
}

\author{
Mahmood Sasa ${ }^{1} \&$ Sierra Curtis ${ }^{2}$ \\ 1 Instituto Clodomiro Picado, Universidad de Costa Rica, San José, Costa Rica; msasa@cro.ots.ac.cr \\ 2 Undergraduate Abroad Program, Organization for Tropical Studies, San Jose, Costa Rica and Swarthmore College, \\ 500 College Ave, Swarthmore, PA 19081.
}

\author{
Received 22-VII-2004. Corrected 25-I-2005. Accepted 30-XI-2005.
}

\begin{abstract}
We observed the mating behavior of the neck-banded snake Scaphiodontophis annulatus (a common species of colubrid in the South Pacific of Costa Rica) in the pre-montane wet forest of Las Cruces Biological Station (San Vito de Java, Costa Rica). Three S. annulatus were observed during courtship between 10-12 AM in a patch of primary forest. The two males were observed to interact with the female, but not signs of male-male agonistic interactions were observed. Their behavior includes grabbing and holding the female, copula, and biting during the copula. Rev. Biol. Trop. 54(2): 647-650. Epub 2006 Jun 01.
\end{abstract}

Key words: snake, Colubridae, Scaphiodontophis annulatus, mating behavior, Costa Rica.

Observations on the mating behavior of Neotropical snakes are uncommon, probably due to the secretive nature of most species and the general low number of encounters in the tropics. Most of the available information on courtship behavior in snakes came from extratropical species (racers: Noble 1937, Shaw 1951, Bennion and Parker 1974, kingsnakes: Kennedy 1978, Murphy et al. 1978, hognose snakes: Plummer and Mills 1996). In general, courtship in snakes involves an initial approach, juxtaposition of male's and female's cloaca and the insertion of one hemipenis, a pattern that is enriched by a diversity of behaviors (e.g. chasing, mounting, jerking, biting and others) depending on the species. For colubrids, Davis (1936) cited two distinct types of mating behavior that he named the "Natrix [=Nerodia $]$ type" and the "Coluber type". This last type includes behaviors observed in viperids and elapids. According to Davis (1936) (see also Gillingham 1974) these two types differ in the first phase of mating: the Natrix type is characterized by an initial approach followed by mounting of the male, while in the Coluber type, the male chases the female for some time before mounting. The Coluber type is also characterized by the presence of jerking motions in one or both sexes. Whether or not these two types reflect phylogenetic relationships within each group is unknown as an evolutionary analysis of mating behavior is not available for snakes.

Here we describe the first observations on the courtship of the neck-banded snake Scaphiodontophis annulatus in Costa Rica. This colubrine species is characterized by a coloration and pattern similar to that of the venomous coral snakes (genus Micrurus) and by extremely long and fragile tails (Henderson 1982, Savage and Slowinski 1996). Presumably, both the coloration and the tail structure are putative defense mechanisms that protect the snakes from predatory attack (Henderson 1984). Scaphiodontophis annulatus is a diurnal species that inhabits the leaflitter of mature wet 
forest from Tamaulipas, Mexico, to northern Colombia (Savitzky 1983, Savage 2002).

On December 1, 2000, while conducting field studies in the pre-montane wet forest of Las Cruces Biological Station (San Vito de Java, Costa Rica) three $S$. annulatus were encountered during courtship. Observations took place between 10-12 am in primary forest and were made using binoculars to minimize disturbance of the snakes. Initially, one bright male (39.0 cm SVL) and one dark colored male (size $\mathrm{cm}$ ) were holding the female $(49.2$ $\mathrm{cm}$ ) on a closed area next to the Gamboa trail. When approaching, we disturbed the snakes from where they were curled beneath a small pile of leaf litter. After the initial disturbance, the female attempted to move away from the males, but was prevented from doing so by both males, who held her with their jaws on the lower third of the body. After the first few minutes, the female lay still for the most part with her head slightly raised, facing away from the males behind her. She occasionally (approximately every 15 minutes) writhed, apparently attempting to rid herself of the males. Following the initial disturbance, the males took turns holding the female with their jaws for approximately ten-minute intervals. While one male was biting, the other appeared to watch the female's head. All bites occurred in an area approximately two thirds of the way down the female's body. The males did not appear to leave prominent tooth marks in the body of the female: upon close inspection later in the day, the only sign of the female having been bitten was a few patches of loosened, flaking skin in the vicinity of the bites.

Approximately 90 minutes after the initial disturbance, both males let her go but continued to watch the female's head. Approximately 105 minutes after the initial disturbance, the female began to move forward. The brighter male bit her, followed afterwards by the darker male, who bit her higher up on her body. At that time the first male let go immediately.
After a few minutes, the dark male let go, and both continued to watch her head. At that point it was not clear if either male was able to copulate with the female, but since we did not observe any of the males entwined with the female's vent, we presume that copulation had not occurred then.

After almost two hours of observation in the field, the snakes were captured, placed in separate bags and transported to the field station. At $1240 \mathrm{pm}$ they were placed in a 50 $\mathrm{cm}$ X $70 \mathrm{~cm} \mathrm{X} 40 \mathrm{~cm}$ aquarium with ca. 3 $\mathrm{cm}$ of leaflitter as substrate. As soon as the female was deposited into the aquarium, she remained immobile, head up some $5 \mathrm{~cm}$ over the substrate. Both males were moving but soon re-oriented towards the female's body and remained still but with intense tongue flicking. The brighter male stayed for 20 minutes with his head close to the female's cloaca. As soon as the female moved, this male bit her at the level of the cloaca and the female responded with a violent movement that released her from the bite. This motion lasted 2 seconds. Eight minutes later the second (darker) male bit the female, and immediately the brighter one did the same, both towards the female's cloaca. A penetrating musk was perceived. They kept this position for 30 minutes, each pulling the female's body. The second male then released the female and kept the same position with his head on top of the female's dorsum. The first male (brighter) continued holding the female and gently pulled her with gentle movements of his head. After five minutes, he became entwined with the female. The male introduced his hemipenis and fluids came from the female's cloaca. Later analysis confirmed that sperm was present in these fluids. They remained entwined for 18 minutes more, apparently in copula. Afterwards the female started to spin and in this way separated from the male. It was $1321 \mathrm{hrs}$, and both males were forced to separate, each moving to an opposite side of the aquarium. After these events, we did 
not observe any further courtship behavior or copulation, even though we kept these snakes in captivity for almost a month.

Our observations reveal that in Scaphiodontophis the females start coital separation whereas in other colubrids it is the male who starts this process (Shaw 1951). Also the pattern of biting in $S$. annulatus differs from biting reported on other colubrines (neck-biting in Elaphe quadrivittata Noble 1937; Elaphe vulpina Gillingham 1974 and Lampropeltis getula Lewke 1979). In those instances, bites occurred at the level of the female's neck both pre and post copula, whereas we observed male $S$. annulatus biting during copula. Gillingham (1974) stated that biting behavior perhaps enhanced the reception of the female, and anchored the male to the female's back. He claimed that it does not seem to be an action to prevent the female's escape since after intertwining the female remained passive throughout coitus. In Scaphiodontophis, however, the role of biting is not clear from our observations: the fact that female ended the coitus so violently and that the successful male maintained the bite during the whole process can be interpreted as a mechanism to hold the female during copulation or a mechanism to stimulate the female's reception.

\section{ACKNOWLEDGMENTS}

We thank Rodolfo Quirós and Luis Diego Gómez for supporting the USAP fall 2000 in Las Cruces Biological Station. Todd Castoe, Alejandro Solórzano and William W. Lamar improved the manuscript with relevant references and revisions. This work was supported in part by Vicerrectoría de Investigación, Universidad de Costa Rica (Project 741-A1-021).

\section{RESUMEN}

El comportamiento de apareamiento es descrito para la serpiente Scaphiodontophis annulatus, una especie de colúbrido común en el Pacífico sur de Costa Rica. El comportamiento incluye capturar y sujetar a la hembra, mordiscos durante la cópula y coito. Dos machos fueron observados al interactuar con una sola hembra, pero no se detectó señales de interacciones antagónicas macho-macho.

Palabras clave: serpientes, Colubridae, Scaphiodontophis annulatus, comportamiento de cortejo, Costa Rica.

\section{REFERENCES}

Bennion, R.S. \& W.S. Parker. 1976. Field observations on courtship and aggressive behavior in desert striped whipsnakes Masticophis t. taeniatus. Herpetologica 32: 30-35.

Davis, D.D. 1936. Courtship and mating behavior in snakes. Field Mus. Nat. Hist. Publ. Zool. Serv. 20: 257-290.

Gillingham, J.C. 1974. Reproductive behavior of the western fox snake Elaphe v. vulpina (Baird and Girard). Herpetologica 30: 309-313.

Henderson, R.W. 1982. An unusually patterned Scaphiodontophis (Serpentes: Colubridae) from Costa Rica. Brenesia 19/20: 359-362.

Henderson, R.W. 1984. Scaphiodontophis (Serpentes: Colubridae): Natural history and test of a mimicry related hypothesis. In R.A. Seigel, L.E. Hunt, J.L. Knight, I. Malaret \& N.L. Zuschlag (eds.). Vertebrate Ecology and Systematics: A tribute to Henry Fitch. Museum of Natural History, The University of Kansas, Lawrence, Kansas, U.S.A.

Kennedy, J.P. 1978. Field observations on courtship and copulation in the eastern king snake and the fourlined rat snake. Herpetologica 34: 51-52.

Lewke, R.E. 1978. Neck-biting and other aspects of reproductive biology of the Yuma kingsnake (Lampropeltis getulus). Herpetologica 35: 54-157.

Murphy, J.B., B.W. Tryon \& B.J. Brecke. 1978. An inventory of reproduction and social behavior in captive gray banded kingsnakes Lampropeltis mexicana alterna (Brown). Herpetologica 34: 84-93.

Noble, G.K. 1937. The sense organs involved in the courtship of Storeria, Thamnophis, and other snakes. Bull. Am. Mus. Nat. Hist. 73: 673-725.

Plummer, M.V. \& N.E. Mills. 1996. Observations on trailing and mating behaviors in hognose snakes (Heterodon platirhinos). J. Herpetol. 30: 80-82.

Savage, J.M. 2002. The amphibians and reptiles of Costa Rica: A herpetofauna between two continents, 
between two seas. The University of Chicago, Chicago, Illinois, USA. 934 p.

Savage, J.M. \& J.B. Slowinski. 1996. Evolution of coloration, urotomy and coral snake mimicry in the snakes genus Scaphiodontophis (Serpentes: Colubridae). Biol. J. Linnean Soc. 57: 129-194.
Savitzky, A.H. 1983. Hinged teeth in snakes: An adaptation for swallowing hard bodied prey. Science 212: 346-349.

Shaw, C.E. 1951. Male combat in American colubrid snakes with remarks on combat in other colubrid and elapid snakes. Herpetologica 149-168. 